\title{
CASTLEMAN'S DISEASE PRESENTING AS A TUMOROUS PARACARDIAC FORMATION
}

\author{
Ivica Vuković ${ }^{1}$, Toni Brešković ${ }^{1}$, Darko Duplančić ${ }^{1}$, Tonči Batinić ${ }^{2}$ Ivana Štula ${ }^{2}$, Cristian Bulat ${ }^{3}$ and \\ Snježana Tomić ${ }^{4}$ \\ ${ }^{1}$ Clinical Department of Cardiology, ${ }^{2}$ Clinical Department of Diagnostic and Interventional Radiology, \\ ${ }^{3}$ Department of Cardiac Surgery, ${ }^{4}$ Clinical Department of Pathology, Split University Hospital Center, Split, \\ Croatia
}

\begin{abstract}
SUMMARY - Castleman's disease (in the literature also known as angiofollicular hyperplasia) is a rare benign lymphoproliferative disease. Clinically, it can manifest as unicentric or multicentric disease. Unicentric disease is most often diagnosed by accident or by symptomatology resulting from compression upon the adjoining anatomical structures. Considering its lymphatic origin, tumor mass can theoretically occur in any body region. We present a case of paracardiac localization of unicentric Castleman's disease in a previously healthy 24-year-old woman. In such clinical cases, the specific localization of the tumor and its radiological properties can pose a differential diagnostic dilemma. Correct diagnosis is only possible after complete surgical excision and histopathologic analysis, which is the optimal therapeutic approach in this disease.
\end{abstract}

Key words: Giant lymph node hyperplasia; Lymphatic vessels; Neoplasms; Rare diseases; Case reports

\section{Introduction}

Castleman's disease (in the literature also known as angiofollicular hyperplasia) is a rare benign lymphoproliferative disease. Clinically, it can manifest as unicentric (UCD) or multicentric (MCD) Castelman's disease. The number of people diagnosed with Castelman's disease each year is not well known, but it is estimated that there are approximately 6500 to 7700 new cases per year in the US 1 . The estimated US 10-year prevalence of MCD was 2.4 per million². The pathogenesis of the disease is not fully understood. Overproduction of interleukin-6 (IL-6) in UCD and both IL-6 and infection with human herpes virus 8 (HHV-8) in MCD have been described as the main etiologic factors ${ }^{3,4}$. Deregulated and overproduced IL-6, par-

Correspondence to: Ivica Vuković, $M D, P h D$, Department of Cardiology, Split University Hospital Center, Spinčićeva 1, HR21000 Split, Croatia

E-mail:vukovic@kbsplit.hr

Received April 13, 2015, accepted November 2, 2015 ticularly in patients with MCD, stimulates the production of acute phase reactants in the liver, resulting in constitutional symptoms including fever, sweats and fatigue, and laboratory anomalies such as anemia, elevated inflammatory markers, hypergammaglobulinemia and hypoalbuminemia ${ }^{5}$. IL-6 also stimulates Bcell proliferation and survival. Additionally, it induces the expression of vascular endothelial growth factor and increased angiogenesis 5 . HIV-associated MCD is uniformly associated with $\mathrm{HHV}-8$ infection, although its prevalence in HIV-negative MCD varies by the local prevalence rate of HHV-8. Plasma levels of HHV-8 DNA correlate with clinical symptoms and predict relapse rates in $\mathrm{HIV}$-associated $\mathrm{MCD}^{6}$. In patients with $\mathrm{HHV}-8$ positive MCD, HHV-8 infected vascular and lymphoid cells express viral analog of IL-6 (vIL-6) thus contributing to the pathogenesis.

Diagnosis of the disease is made by excisional biopsy of affected lymph node tissue. In cases of deeper and less accessible disease, core needle biopsy is preferred over fine needle aspiration, since fine needle aspiration 
is insensitive for both UCD and MCD ${ }^{5}$. Castleman's disease can be divided into 3 histopathologic subtypes: 1) hyaline-vascular (the most common, $80 \%-90 \%$ of all cases), 2) plasmacellular (10\%-20\% of cases), and 3) mixed type $e^{7}$ UCD is common in younger patients that are in their $3^{\text {rd }}$ or $4^{\text {th }}$ decade of life ${ }^{7}$. It usually progresses without symptoms and is characterized by a relatively large, i.e. bulky, slowly growing tumorous mass. UCD is most often diagnosed by accident or by symptomatology resulting from compression upon the adjoining anatomical structures. Considering its lymphatic origin, tumor mass can theoretically occur in any body region. However, the most common localization is mediastinum, more specifically anterior mediastinum, right paratracheal, lung hilum and posterior mediastinum $^{3}$. The patient may sometimes experience nonspecific disturbances similar to B symptoms such as weight loss, loss of appetite, night sweats, fever that is sometimes accompanied by increased erythrocyte sedimentation rate, increase of serum C-reactive protein concentration and polyclonal gammopathy on serum protein electrophoresis. All these symptoms are the result of increased IL- 6 production, and are almost exclusively associated with the plasmacellular histologic subtype ${ }^{3,8}$. Therapy of choice for unicentric form of the disease is total surgical excision of the tumor with very low incidence of relapse ${ }^{8,9}$. For the disease that cannot be completely excised, radiation therapy is recommended ${ }^{10,11}$. In selected patients who are not candidates for surgical resection or radiotherapy, partial resection or clinical observation alone can be sufficient. However, if the disease becomes symptomatic, systemic treatment should be considered ${ }^{5}$.

Multicentric Castleman's disease is more typical in older patients $\left(6^{\text {th }}\right.$ decade of life) or in HIV positive patients regardless of age $\mathrm{e}^{3,10}$. HIV infection is an important risk factor for MCD, and all patients with $\mathrm{HIV}$-associated MCD are coinfected with $\mathrm{HHV}-8^{5}$. Systemic inflammatory manifestations similar to B symptoms (fever, night sweats, weight loss and fatigue) characterize the vast majority of MCD patients. The usual findings during physical examination are general lymphadenopathy, hepatosplenomegaly, with many patients presenting with fluid retention (lower extremity edema, pleural or pericardial effusions, or ascites). Common hematologic abnormalities include anemia, elevated inflammatory markers (erythrocyte sedimentation rate and C-reactive protein), hypergammaglobulinemia and hypoalbuminemia. The presentation of the disease can vary ranging from indolent or slow progressing to acute and fulminant. Some patients may experience relapsing-remitting course of the disease ${ }^{5,12}$. In case of concomitant infection with $\mathrm{HIV}$ and HHV-8, additional symptomatology is possible (low T-cell CD4 count, opportunistic infections, occurrence of Kaposi sarcoma or primary effusion lymphoma, etc.). The recommended treatment of choice is systemic monotherapy with the anti-CD20 monoclonal antibody rituximab ${ }^{12-15}$. Therapy with glucocorticoids offers short-term control of the symptoms, however, complete remissions are rare and shortlived ${ }^{3,16}$. In patients with coinfection with HIV and/or HHV-8, antiretroviral therapy together with antiviral therapy (valgancyclovir or gancyclovir) should also be initiated. As second-line treatment in HIV negative patients, the anti-IL-6 monoclonal antibody siltuximab is recommended ${ }^{5}$. Further lines of treatment involve administration of single-agent or combination of chemotherapeutics (etoposide, vinblastine or liposomal doxorubicin). Currently, there are clinical trials investigating therapy with siltuximab and tocilizumab in $\mathrm{HIV}$ positive $\mathrm{MCD}^{5}$.

\section{Case Report}

A previously healthy 24-year-old woman was observed at Surgical Emergency Unit of the Split University Hospital Center because of protracted back pain that occurred 2 days earlier when she suffered a traffic accident. As part of diagnostic workup, chest radiography was performed. It showed a suspect tumorous mass localized in the anterior mediastinum. Urgent investigation was further extended by multislice computed tomography imaging (MSCT) of the thorax and transthoracic echocardiography that raised suspicion of left ventricle pseudoaneurysm (Fig. 1). The patient was hospitalized at the Department of Cardiology, Split University Hospital Center. Using MSCT angiography, the mass was characterized as a well vascularized, irregular, expansive tumor localized adjacent to the left ventricle, measuring $3 \times 6.3$ $\mathrm{cm}$ in diameter. Thus, the diagnosis of left ventricle pseudoaneurysm was excluded and the mass showed properties similar to hemangioma. Imaging analysis 


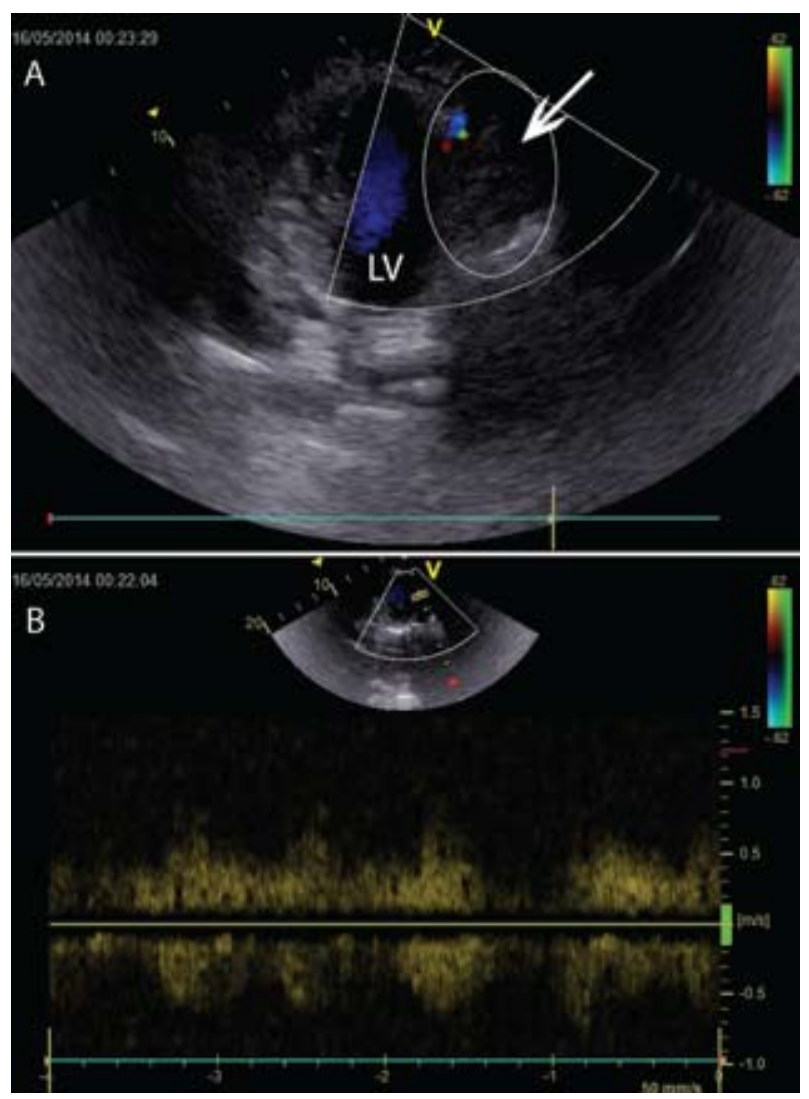

Fig. 1. Transthoracic echocardiography image showing paracardiac tumor mass (within ellipse, marked by arrow) adjacent to the left ventricle (LV) - panel $A$. The tumor was well vascularized, pulsed Doppler flow-line spectrum indicating low resistance flow-panel B.

Fig. 2. Digital subtraction angiography showing vascularization of the tumor. Cranial portion of the tumor was irrigated from the left internal thoracic artery (LIMA), corresponding to feeding artery indicated by the arrow panel A. Caudal portion received arterial supply from celiac trunk - Panel B. Venous branches were part of the left brachiocephalic trunk basin-panel C.

was further extended by digital subtraction angiography (DSA), which also showed exceptional vascularization of the tumor (Fig. 2). Cranial portion of the tumor was irrigated from the left internal thoracic artery (mammary artery), while caudal portion received arterial supply from celiac trunk. Venous branches were part of the left brachiocephalic trunk basin. By using magnetic resonance imaging of the heart, the

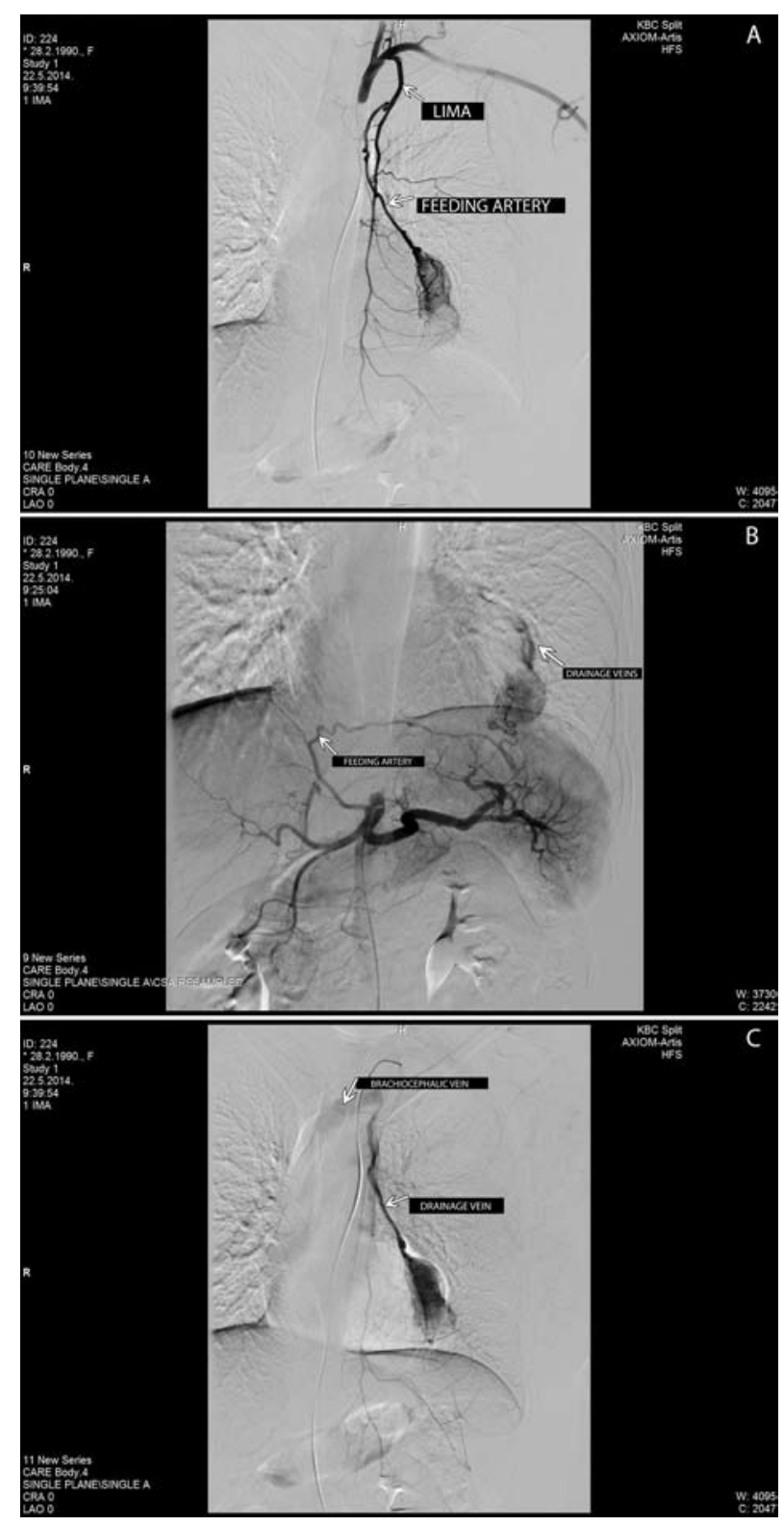

neoplasm was visualized as a solid mass with smooth contours, very well imbibed and vascularized, without signs of myocardial and/or pericardial invasion (Fig. 3). Finally, the early diagnosis of hemangioma was established and the cardiology-cardiac surgery team made a decision to perform full excision of the tumor. The operation was performed successfully and without further complications (Fig. 4). Histopathologic 

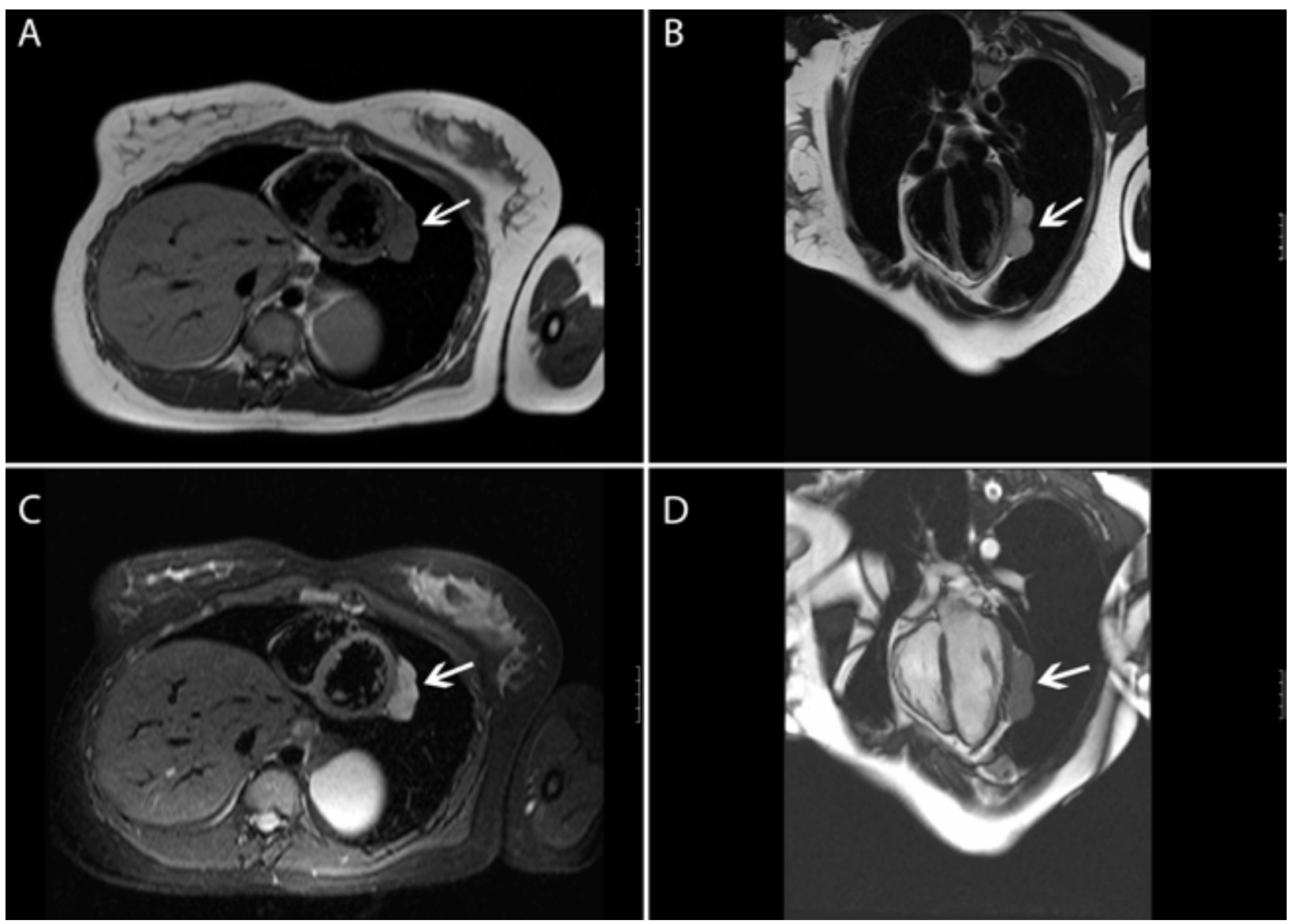

Fig. 3. Magnetic resonance imaging of the heart and paracardiac tumor mass (indicated by arrow). Panel $A$ shows $T 1$ weighted sequence, panel B T2 weighted sequence, panel $C$ turbo inversion recovery magnitude (TIRM) sequence, and panel $D$ true fast imaging with steady state free precession (TRUFI) sequence.

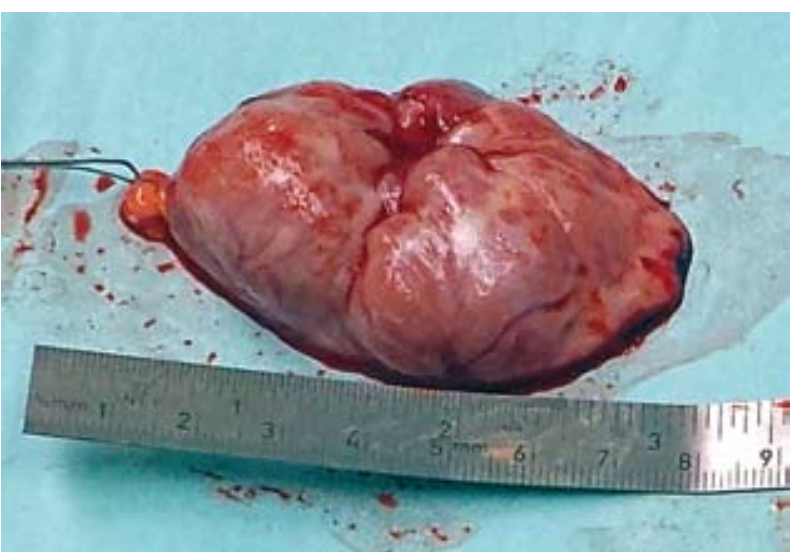

Fig. 4. Macroscopic appearance of the tumor after excision. analysis of the tumor showed the lymph node tissue that had features characteristic of the hyaline-vascular type of Castleman's disease (Fig. 5). Currently, the patient undergoes regular medical check-ups and she is without any symptoms and signs of relapse of the disease.

\section{Conclusion}

Castleman's disease is a very rare entity and thus there is a scarce number of epidemiological studies. Mediastinal localization has been presented in the majority of published cases. However, paracardiac localization has not been described previously. In this clinical case, specific localization of the tumor and its 

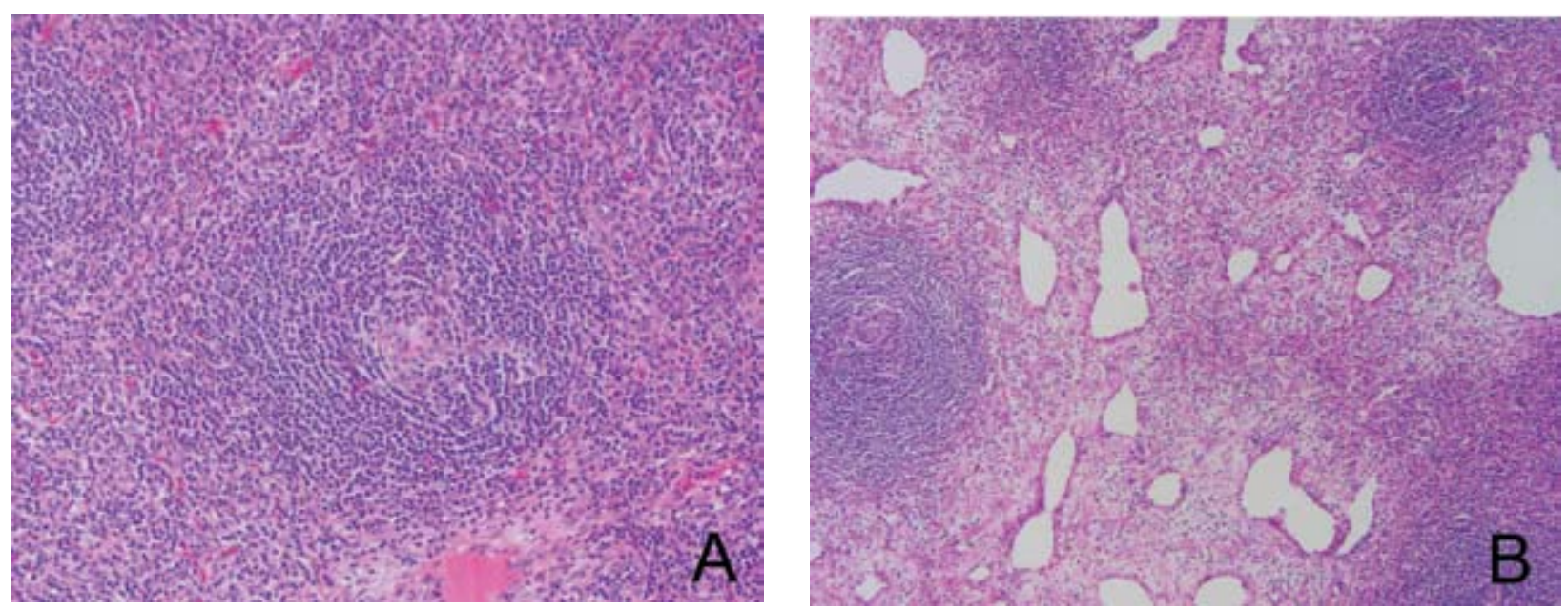

Fig. 5. Histopathologic appearance of the tumor tissue. Panel A: lymphoid follicle with partially involuted germinal centre and penetrating arteriole surrounded by concentric layers of small, uniform lymphocytes (hematoxylin and eosin stain, magnification 400×); panel B: interfollicular zone: numerous blood vessels with hyperplastic endothelial cells surrounded by cuffs of collagen (hematoxylin and eosin stain, magnification 100×).

radiological properties can pose a differential diagnostic dilemma and can clinically impose as (pseudo) aneurysm of the left ventricle or hemangioma. Therefore, correct diagnosis is only possible after complete surgical excision and histopathologic analysis, which in this case is the optimal therapeutic approach.

\section{References}

1. The Castleman Disease Collaborative Network (CDCN) [Internet]. How prevalent is Castleman disease? [cited 2015 Jul 28]. Castleman's Awareness \& Research Effort. Available from: http://www.cden.org/about-castleman-disease

2. Robinson D Jr, Reynolds M, Casper C, Dispenzieri A, Vermeulen J, Payne K, et al. Clinical epidemiology and treatment patterns of patients with multicentric Castleman disease: results from two US treatment centres. Br J Haematol. 2014;165:39-48, http://dx.doi.org/10.1111/bjh.12717

3. Herrada J, Cabanillas F, Rice L, Manning J, Pugh W. The clinical behavior of localized and multicentric Castleman disease. Ann Intern Med. 1998;128:657-62.

4. Polizzotto MN, Uldrick TS, Wang V, Aleman K, Wyvill $\mathrm{KM}$, Marshall V, et al. Human and viral interleukin- 6 and other cytokines in Kaposi sarcoma herpesvirus-associated multicentric Castleman disease. Blood. 2013;122:4189-98, http://dx.doi.org/10.1182/blood-2013-08-519959

5. Soumerai JD, Sohani AR, Abramson JS. Diagnosis and management of Castleman disease. Cancer Control. 2014;21:26678.
6. Stebbing J, Adams C, Sanitt A, Mletzko S, Nelson M, Gazzard B, et al. Plasma HHV8 DNA predicts relapse in individuals with $\mathrm{HIV}$-associated multicentric Castleman disease. Blood. 2011;118:271-5, http://dx.doi.org/10.1182/blood2011-02-335620

7. Keller AR, Hochholzer L, Castleman B. Hyaline-vascular and plasma-cell types of giant lymph node hyperplasia of the mediastinum and other locations. Cancer. 1972;29:670-83.

8. Rose C, Mahieu M, Hachulla E, Facon T, Hatron PY, Bauters F, et al. POEMS syndrome. Rev Med Interne. 1997;18:553-62.

9. Talat N, Belgaumkar AP, Schulte KM. Surgery in Castleman's disease: a systematic review of 404 published cases. Ann Surg. 2012;255:677-84, http://dx.doi.org/10.1097/ SLA.0b013e318249dcdc

10. Chronowski GM, Ha CS, Wilder RB, Cabanillas F, Manning J, Cox JD. Treatment of unicentric and multicentric Castleman disease and the role of radiotherapy. Cancer. 2001;92:670-6.

11. Noh OK, Lee SW, Lee JW, Kim SY, Kim CS, Choi EK, et al. Cases report of unicentric Castleman's disease: revisit of radiotherapy role. Radiat Oncol J. 2013;31:48-54, http:// dx.doi.org/10.3857/roj.2013.31.1.48

12. Bower M, Newsom-Davis T, Naresh K, Merchant S, Lee B, Gazzard B, et al. Clinical features and outcome in HIV-associated multicentric Castleman's disease. J Clin Oncol. 2011;29:2481-6, http://dx.doi.org/10.1200/ JCO.2010.34.1909

13. Casquero A, Barroso A, Fernandez Guerrero ML, Gorgolas M. Use of rituximab as a salvage therapy for HIV- 
associated multicentric Castleman disease. Ann Hematol. 2006;85:185-7.

14. Hoffmann C, Schmid H, Muller M, Teutsch C, van Lunzen $\mathrm{J}$, Esser $\mathrm{S}$, et al. Improved outcome with rituximab in patients with HIV-associated multicentric Castleman disease. Blood. 2011;118:3499-503, http://dx.doi.org/10.1182/blood-201102-333633
15. Marrache F, Larroche C, Memain N, Bouchaud O, Robineau $\mathrm{M}$, Hermine $\mathrm{O}$, et al. Prolonged remission of $\mathrm{HIV}$-associated multicentric Castelman's disease with an anti-CD20 monoclonal antibody as primary therapy. AIDS. 2003;17:1409-10.

16. Summerfield GP, Taylor W, Bellingham AJ, Goldsmith HJ. Hyaline-vascular variant of angiofollicular lymph node hyperplasia with systemic manifestations and response to corticosteroids. J Clin Pathol. 1983;36:1005-11.

Sažetak

\section{CASTLEMANOVA BOLEST KOJA SE PREZENTIRALA KAO TUMORSKA PARAKARDIJALNA TVORBA}

\section{Vukovic, T. Brešković, D. Duplančić, T. Batinic, I. Štula, C. Bulat i S. Tomić}

Castlemanova bolest (u literaturi još poznata kao angiofolikularna hiperplazija) je rijetka limfoproliferativna bolest dobroćudnog tijeka. Klinički se manifesira kao lokalizirana i multicentrična. Dijagnoza lokalizirane bolesti se najčešće postavlja slučajno nakon obrade simptomatologije uzrokovane kompresijom tvorbe na okolne anatomske strukture. S obzirom na njeno limfatičko podrijetlo tumorska masa se može pojaviti u bilo kojem dijelu tijela. Prikazujemo slučaj parakardijalno lokalizirane Castlemanove bolesti kod prethodno zdrave 24-godišnje žene. U ovakvom slučaju, zbog specifične lokalizacije i radioloških obilježja tvorba može predstavljati diferencijalno dijagnostičku dilemu. U tom slučaju točna dijagnoza je moguća tek nakon potpune kirurške ekscizije i patohistološke analize, što u slučaju ove bolesti ujedno predstavlja optimalan terapijski pristup.

Ključne riječi: Limfni čvorovi, hiperplazija; Limfne žile; Tumori; Rijetke bolesti; Prikazi slučaja 